\title{
INTER-FAITH BELIEVER'S CONFLICTS AND ITS SOLUTIONS IN NORTH SUMATRA INDONESIA
}

\author{
Arifinsyah \\ Universitas Islam Negeri Sumatera Utara (UINSU) Medan \\ arifinsyah@,uinsu.ac.id
}

\begin{abstract}
The aim of this study is to find out the root of the conflict and its solution proposed by the religious leaders to maintain the harmony among religious believers. After conducting a qualitative research, the results show that the conflict in this region is more dominant coming from the economic resources, not because of religious teachings. Besides, they are also caused by the behaviour of the believers concerning to religious cultural identity but they are relatively small. The solutions given by the leaders indicate that (1) building up the commitment of togetherness among the leaders, (2) the support of the public leaders in mediating the conflicting believers, (3) the multiple role of the leaders in socializing the universal values of the religious teaching and the local wisdom, and (4) doing inter-faith and inter-ethnic dialogues among the believers honestly, openly, respectively. By doing these, the excellence and the national harmony in north Sumatera will come true.
\end{abstract}

Keywords: inter-faith believer's conflicts, national harmony

\section{Abstrak}

Tujuan dari penelitian ini adalah untuk mengetahui akar dari konflik dan solusi yang diajukan oleh para pemuka agama untuk menjaga kerukunan umat beragama. Setelah dilakukan penelitian kualitatif, didapatkan hasil bahwa konflik di wilayah ini lebih dominan bersumber dari sumber daya ekonomi, bukan karena ajaran agama. Selain itu, juga disebabkan oleh perilaku pemeluk agama yang terkait dengan identitas budaya agama namun relatif kecil. Solusi yang diberikan oleh pemimpin menunjukkan bahwa (1) membangun komitmen kebersamaan antar pemimpin, (2) dukungan pemimpin masyarakat dalam memediasi konflik pemeluk agama, (3) peran ganda pemimpin dalam mensosialisasikan nilai-nilai universal. tentang ajaran agama dan kearifan lokal, dan (4) melakukan dialog antaragama dan antaretnis antar umat beriman secara jujur, terbuka, masing-masing. Dengan demikian akan terwujud keunggulan dan kerukunan bangsa di Sumatera Utara.

Kata Kunci : Konflike Antar Umat Beragama, Kerukunan Bangsa 


\section{Introduction}

Harmony is not something that is taken for granted, but to maintain and preserve the harmony necessary coaching process is continuous. Similarly, religious harmony in North Sumatra that are constantly changing in line with the dynamics of globalization in a pluralistic society. Though far North Sumatra recognized as a national barometer in terms of harmony, but not necessarily forever. On the one hand the diversity and plurality that become treasures of the wealth of the nation as an adhesive and integrity, unity and build a future together. But on the other hand, if diversity was not empowered and wisely laid out, then it is likely to be the threat of conflict, either vertically or horizontally which is not the least casualties.

Republic of Indonesia is the fourth largest country in the world based on total population, which is inhabited by 250 million people. The majority of the population is Muslim. There are at least six official religions and hundred beliefs, all of which may not be uniform. The plurality also led to changes in the structure of society, and the future will become increasingly complex. One of these factors is caused by migration and social mobility are very dynamic. In the future there may be a place hardly homogeneous. Similarly, large differences in diversity at the same time, if there is no institution called tolerance, will have implications for the opening of the conflict.

Conflict smelling religion in Indonesia is still very latent. The last five years have occurred hundreds of cases of violation of freedom of religion which includes coercion will, vigilantism, harassment and violence. In addition, there is a few cases of violations of religious freedom are often cited people both at home and abroad. Some examples of these large cases; ranging from cases HKBP Ciketing protracted since 2010, continued mass violence against the Ahmadiyah community in Banten Cikeusik, burning of three churches in Waterford, suicide bombs in mosques and in GBIS Police Ceribon Solo, burning Shiite boarding school in Sampang, and the burning of two mosques in the district range Kuasan Aek - North Sumatra.

Right now, faced with the challenge of religious conflicts or the appearance of conflict between them. The most actual is conflict among religious believers. Potential outbreak of conflict is enormous, distinctions of humanity into the limits of objective and subjective civilization. According to P. Huntington (1993: 12), objective barrier elements are language, history, religion, customs, and institutions. 
Limiting element is the identification of a human. The difference between the barrier is real and important (P. Huntington, 1993: 12). Unconsciously, people clustered into the identities that distinguish between one another.

Looking at the way religious communities in Indonesia and North Sumatra in the reform era, the reality faced with a number of religious harmony disorders and the potential for conflict. The conflict there that has not been completed, and so many have done well, and can be accepted by the parties to the conflict. It is quite interesting to put forward, because to this day is still the star of North Sumatra and the barometer of national harmony. The question in this study that will be answered is what is at the root of conflict in North Sumatra and potential solutions?

\section{Research Methods}

This research used qualitative research that sourced from various references, focusing on the study of the text in depth about the content and the meaning as well as structure and discourse. The intended of the text is not only written narratives that taken from scriptures, newspapers, literature, but also the results of dialogues which held in many seminars. As understood that qualitative research is a research process to address human or social problems by creating a comprehensive and complex picture that presented in words, reporting detailed views obtained from sources of information, and done naturally. By direct observation, plus source information and reading results from various literature, then the content analysis analysed on references and inter-faith believer's conflicts and its solutions in North Sumatera Indonesia.

\section{Demographics of North Sumatra}

North Sumatra Province is the fourth largest province in Indonesia with a population of approximately 15 million people. The majority of the population are Muslims reach $65 \%$, then $26 \%$ of Protestants, and the rest are Catholic, Buddhist, Hinduism and Confucianism. In North Sumatra, the community is quite heterogeneous, multi-ethnic, cultural and religious diversity be unique for this area. The uniqueness of it is also seen in the diversity of the governor who led North Sumatra since its inception until now seventeen Governors are ethnic Mandailaing, Toba Batak, Malay, Minang, Nias, Karo and Java. In addition to the different ethnic, 
when viewed from the origin of religion, the religion of the Governor of North Sumatra also alternated between Islam and Christianity (Agustono et al. 2013: 4). In our opinion, the spirit of multicultural, cultural and religious plurality should be strengthened to build the province of North Sumatra became powerful, innovative, competitive, and resilient to changes. If the spirit is not managed properly, it can threaten the integrity and unity of the nation, as well as anxiety in the community.

North Sumatra Province has a special character compared with other regions in Indonesia. This brings the uniqueness of the area. On the one hand the uniqueness it brings various benefits to people's lives and on the other hand it can also cause a trigger source of social tension. The pattern of development in this area needs to be designed very carefully, because if it is done with an approach that does not consider the social diversity, will certainly lead to unwanted consequences. But on the other hand, it is also necessary to understand that is not always the initiative to go to the harmony played by government officials. Sometimes, it appears the creative efforts of the people themselves independently, while in essence it is not planning a harmony society because society activities that stems from their need to build social relations through various customs systems and local wisdom.

A historical inevitability that in North Sumatra into the meeting area religions. Historically, before the great religions go into this area, the archipelago are native beliefs that can be classified animism and dynamism, is Parmalin, Pelbegu, and Pemena. Then it came successively Hinduism, Buddhism, Islam, and Christianity, Confucianism later. Contiguity can cause conflicts that could dismember national integration. Therefore, if the conflict is not managed properly, it will endanger national stability.

With the plurality, this area frequently targeted by certain groups either conflict-related issues religious and ethnic. Fortunate people of this region are always able to manage it so that potential conflicts do not develop into the things that are not desirable. With the ability to cooperate and coordinate intensive, it can manage potential conflicts become treasures of the nation's wealth, so that this region becomes relatively safest province in the country. Therefore, it is not surprising that North Sumatra has always been a barometer in the handling of potential conflicts. One of the tricks that are done together with the Government and the elements of existing forums to resolve potential conflicts. In addition, carry out an intensive 
dialogue with religious leaders and community leaders. However, the facts of history prove that in North Sumatra unheard of social unrest and open conflicts. This is due to the wisdom of the government in maintaining and preserving the harmony pillars, namely the Forum community leaders, religious leaders, youth empowerment forums and government concern to the diversity aspirations.

\section{Roots and conflict in North Sumatra map}

In the globalization era barriers between peoples and cultures becomes increasingly thin, even in some cases disappear. So that disturbances of national unity can hit unexpectedly, if this nation is not in standby and alert. In religious views, the challenges ahead, among others, social harmony, unity and integrity, should be retained as one of the things that is very important and which occupies a prime position. Social issues, economics and politics that makes religion as vehicles can also lead to internal conflicts and inter-religious, giving rise to split the nation, riots, security disrupted. If religion is exploited for political purposes, then religion should be able to create an atmosphere cool and peaceful, would turn into a conflict arena and into the background harmony non-religious. In addition, factors religious ignorance of the teachings of their religion, their defiance of the existing regulations and to impose the will, also be a factor in the conflict.

Tension and intra and inter-religious conflicts that often turned violent, which always arise from time to time. Therefore, it is not uncommon to make the public figure and the public assume an increase in intolerance in the middle of the intra and inter-religious environment, but also in the life of the nation, things that can threaten national unity and existence of the nation of Indonesia (Azra, 2002).

Conflict is strife, dissension and conflict between the characters in the other figures, two figures or conflict, the conflict caused by the presence of two or more ideas or desires of individual self-control contradictory thus affecting behaviour (IMEC 1989). From this definition it includes things that conflict including conflict in war, physical fights, disagreements, or the difference between the desire to what is done.

Thus, the term conflict is used in this paper is a conflict between an individual and a group or two things for which there is no difference either in the form of ideas, words, or physical, either covertly or overtly. Where it is done by 
religious people, both internal religious communities, religious groups and external inter-religious government.

Theoretically at the root of conflict in society and the nation is due to three factors, namely Security, Identity, and Resources. Sense of security, identity, and source of income. It is threatened if not met or are potentially create social conflicts have fatal consequences. Conflicts can occur in a variety of scales, among others; mass-scale conflict, conflict non-bulk, and inter-religious tensions, such as some cases of tension in the establishment of houses of worship and religion spread to other groups that have a religious as well as defamation of religion.

Understood from the sociological approach, psychological conflict can be regarded as a reflection of the psyche in order to social interaction. The existence of this conflict shows that individual psychic energy is something that is dynamic. Because the conflict was constantly changing shape and progressing, then the causes of the conflict is quite a lot.

According to Fathurrahman $(1986,238)$, there are some potential conflicts, among others:

1. Prejudice; is the result of a process of interaction between individuals and groups in the form of attitudes, perceptions, ways of thinking and feeling toward another person or group.

2. Ethnocentric; a particular ethnic group tend to feel better group than other ethnic groups, even the best feel.

3. Discrimination; originated from the intense and ethnocentric prejudice fanatic who then will bring rulings stereotypes of other groups, to make a profit-oriented economy and politics.

4. Economic disparities; due to differences in the excesses of the economic resources, resulting in the accumulation of wealth on an individual or group, while the other person or group collapsed and the poor.

5. Differences in ideology; especially religion often becomes a trigger of conflict. Each individual or group will assume that the notion of ideology or their religion is at its best. While ideology or religion of others is wrong. (Fathurrahman, 1986:238)

The conflict among the religious communities can arise caused by excessive religious emotion, a sense of danger among each other, the displacement between 
religion, the establishment of houses of worship are less qualified, any pets that disturb public tranquillity and so forth. Problem is too sensitive is the information forming the actual particular religious congregation traditionally is becoming adherents of other religions. This means developing an attitude here that equate the term religion with ethnicity. This case can arise in the Christian Church congregations Aceh in Medan.

The constellation of potential conflicts between religious communities in North Sumatra can be pointed out as follows: Pluralistic society in this area from the perspective of the background ethnicity birth problems is the lack of the concept of the dominant culture. When called dominant Malay community, but the social reality of this ethnic group has not been on since the layer of strategic groups because of historical factors. Batak society though seen from quite a dominant role in society, but among themselves there still seem to agree on the meaning of the word "Batak", whether merely as an explanation of the background of the historical roots, genealogical ties, or have a theological meaning. Toba Batak people seem inclined to the latter, while those in the South more notice it at first.

Potential conflict becomes vulnerable in fostering religious harmony in North Sumatra, including the matters is as follows:

a. Establishment of the synagogue which is not in accordance with the legislation in force.

b. Religious broadcasting to people who have a particular religion with material rewards, it is a lot happening in the remote areas.

c. The existence of a group that secretly pitting people by spreading leaflets or redistributed photocopies and the like.

d. Personal disputes, groups, organizations eventually evolved into a religious conflict.

e. The struggle for livelihoods or natural resources and agrarian conflicts.

f. The use of dwelling house or shop house into a place of worship. (FKUB North Sumatra, 2008:9)

Problems surrounding the establishment of Houses of Worship be that complicated issues in this area. It was preceded by the difference in concept between Islam and Christian generosity. For those Muslims who come from different organizations can conduct worship at the mosque praying together, Musolla 
irrespective of differences of race, ethnicity, language, and organization. Therefore, the establishment of a house of worship on the motivation of the Muslims against the background by the capacity that can be accommodated by a mosque. Instead of Christianity among the various sects formed above, the flow rate as well as difficult for them to become a church into a place of worship together. Therefore, the establishment of houses of worship evolved spirit in every sect which sometimes lead to social friction as happened some time ago in Langkat, namely the destruction of the newly established house of worship.

There is an impression in harmony during these dialogues that for Muslims, Christians were being offensive with a burst of his proposals on the question of the establishment of houses of worship, while for the Christians gained the impression that the view of the Muslims seized with inferiority complex. As a result of discussion about the way of the establishment of houses of worship often have a winding road. What about this cannot be in the travel patterns and other approaches that approaches personal relationships between characters, not through legal formalities approach based on formal juridical rules.

The existence of indulgence in some Christian circles that raising animals for offending Muslims worship aspect. On the one hand there is an offensive stance care for the animal, while the neighbours were Muslims perform self-defence efforts. Similarly, the attitude of the majority of Christians open a shop or restaurant that is brightly-lit animals writes provision in question. This attitude then offset also by the majority of Muslims founded the restaurant that uses the sign that indicates its religious identity.

Christianization and Islamization issues surrounding still often appears on the surface which then evolved to understanding the implications of the majority and minority. This stems from movements on the part of Christians is so intense that missionary activities. Similarly, the attitude shown by some Muslim preachers who are so heavily impressed open space conflicts with other faiths. Cross over spirit proselytes or someone from the old faith to the new faith perceived as a limiting factor in knitting social harmony in this area.

Anarchism smelling religion can also be sourced from the social conditions that tend to remain vulnerable. At the same time, social and cultural disorientation and dislocation, economic deprivation, globalization, and the like as well are also 
important factors for the emergence of splinter religious groups. The splinter groups often take the form of a cult, a very exclusive, closed and centred on a person who is considered charismatic. These groups with certain eschatological dogma even looking at the world was coming to the end times and the apocalypse. Doctrine and theological-eschatological view like this, the other could not immediately be able to elicit a reaction from mainstream religions, which can lead to social conflict (Azra, 2002).

In line with the jargon of development in the past, then the accelerated program and modernization it makes the marginalization of traditional elite figures both among religions and customs. This further resulted in loss of grip when the community and want to find a new reference to the intermediary culture (cultural broker), then when this character is hindered by its traditional elite and the public then has the option to serve as a reference discretion. So that's when various deviant behaviour, religion, law, morals and traditions into a common view of the everyday. So, what happens is powerlessness, both bureaucratic and religious leaders to reestablish the social manners. Social ills such as ninja, brawl, gambling, prostitution and so if people do not have the empowerment to overcome it.

Well recognized that social harmony in this area is not a finished product that means it will continue to be the pillars. It will depend on the attitude and response, both from the public and bureaucratic apparatus. Religious leaders and communities in this area have been aware of it. For that, they seemed to have agreed that the pattern of relationship harmony must be built through appropriate engineering interventions and expected by people itself. To that end, later made an intense effort to build new communicates religious leaders and administrative automatically.

The existence of a theological differences with other religions may not be denied because each religion came with different backgrounds welfare. To that end, any religious leader to his people should always be aware, that every religion has two truths at once the truth of normative and practical. Normative truth is that only can be understood, perceived and practiced by adherents of the religion itself. Being practical truth of religion is the religion of humanity that can not only be felt by the adherents of the religion but also by adherents of other religions. Therefore, communication between leaders and followers of the religion is possible. 


\section{Resolution and conflict resolution efforts}

The term "resolution" is a unanimity of opinion in the form of a judgment or demand or demands set by the meeting (meetings, or hearings), written statements, usually containing about something, or finally issued a meeting that will be submitted to the government (IMEC, 1989: 837). In the dictionary, "An-English- Indonesian Dictionary" The term resolution "resolution" is defined by solving, or determination (M. Echols, 2000:481). While in the "Dictionary of Popular Science", the resolution is defined decisions, separation, proposal, with firm determination (Widodo et al. 2002, 647). Thus, the resolution is understood as efforts to solve or resolve problems relating closely to the clash between individual to individual, and between minority groups with the majority of Moslems and Christians in North Sumatra.

Robert John Ackermann in his book "Religion for Critics" explains that in the legal system, individuals in conflict, and their conflicts resolved J. Ackermann :1997). Efforts completion and solving conflicts between individuals intended religiosity is what can be understood as a conflict resolution the majority and minority. Therefore, there must be a problem any resolution, including issues related to majority and minority faiths of Islam and Christianity in North Sumatra. One of the most appropriate resolution efforts undertaken by religious communities in North Sumatra in handling the majority and minority groups are uniting in a common understanding of beliefs and belief in the teachings of their respective religions. In this case religious adherents in North Sumatra has been working in all respects. The attitude of equality between the majority and the minority and do not highlight the differences between them are significant. Therefore, conduciveness majority and minority religions in North Sumatra should get praise, because of race, religion, culture and customs, they live in the frame brotherhood.

In addition, another resolution is to put forward the concept of multiculturalism (Atho, 2004: 11), so dilute exclusivism attitudes among majority groups and minority religions woke social integrity that is more conducive in various sectors of life, stability and security in the region, strengthening the existence of both parties in the development of solidarity regionalism in North Sumatra, and nationality, thus forming a harmonious atmosphere of life, harmony and peace between the majority Muslims and minority Christians, the opposite can also create a safe atmosphere and peace among Christians and Muslims are majority minority . 
So much conflict of public interest lately that influenced the diversity of perspectives, which is sourced from religions. Religions are supposed to create peace instead disrupt life. Religion should contribute it comes to serve the spiritual inspiration and moral depravity often appear so terrible destroyer machine. Religion should be a spiritual oasis of coolness it is now the most destructive latent danger. Being nests excessive narcissism fellow human oppressors. And due to act of a group of religious extremist elements not only interfere with the other groups, but also the essence of religion and destroy itself.

In general, the condition of internal harmony and inter-religious in North Sumatra remains conducive and controlled, although in some areas and conflicts that occur conflict immediate attention and resolution. But some are still in the process of settlement which, if allowed or not quickly find a solution would be to threaten national unity. Since the establishment of Sumatra FKUB until now quite varied disputes and potential conflicts in the community interfaith harmony as a nuisance the past four years, among other things:

1. Development GKPS Church in the Village District of Buntu Pane Asahan. The existence of civil unrest in the Village District of Buntu Pane Asahan District because of the development activities of the Church GKPS that does not meet the administrative requirements as set forth in Article 14, 15 and 16 Joint Regulation of the Minister of Religious Affairs and the Minister of Home Affairs No. 9 and 8 of 2006 and the establishment of a written request synagogue has not received the relevant agencies. This problem has been discussed at the board meeting FKUB Asahan and for subsequent settlement of this issue will be addressed by the Government Asahan.

2. Development GBKP Church in the village of Pinto Gung Karo District of Naman Teran. The objections of citizens on the development of the Church in the Village GBKP Gung Pinto Karo District of Naman Teran. This problem has been resolved by Karo FKUB by consensus.

3. Meitreya Vihara Development in Sub Cliffs range Jaya Sub City West range, Asahan District. The presence of MUI rejection letter Asahan because this monastery establishment Great Mosque adjacent to the range. FKUB Asahan been researching paperwork and surveys in the field, and has issued a recommendation FKUB establishment of houses of worship, then the 
problem is still in Asahan Religious Affairs as the Head Office of the Department of Religious Asahan District still has not issued a recommendation establishment of houses of worship.

4. House which is used as a house of worship in the Church of Antioch GBI cliffs Indah Permai Housing Complex at Link. 02 Ex. Main airports district. Cliffs City, High Cliff. The presence of community members cliffs Indah Permai Housing Complex at Link. 02 Ex. Main airports district. Cliffs City, High Cliff who objected to the activities and whereabouts GBI Antioch. FKUB High Cliff has had a dialogue with community representatives Indah Permai Housing Complex cliffs and research in the field as well as receive confirmation from the Village Head of Bandar Utama. The next plenary meeting of the High Cliff State FKUB board decided to recommend the use of the building instead of the synagogue as a house of worship not later than 2 (two) years. (Already two years, 2008-2010).

5. Establishment synagogue HKBP Resort New Binjai, Binjai City. Environmental objections residents Jati Makmur Village II Binjai City for the establishment HKBP synagogue. FKUB Board and Advisory Board FKUB Binjai Binjai City on June 2, 2008 meeting agreed that settlement of this matter submitted to the City of Binjai.

6. Hall of treatment that serves as a monastery in the town of Tanjung Balai. The existence of the public mind because of new building permits as a clinic but made the synagogue. This problem has not been completed and will be discussed again at the board meeting FKUB Tanjung Balai.

7. The burning of synagogues and houses of Christians in the District Sibuhuan Barumun Padang Lawas. Community objections over the construction of the Church which is in the Village Market Environment VI Sibuhuan Barumun District of Padang Lawas regency. Residents abuzz went to the location and establishment of the synagogue quickly in case of fire 1 (one) unit of the synagogue and two (2) units of houses of Christians. This problem has been resolved by the officials Plus Padang Lawas and government facilitates freedom of worship for Christians and find a location that is more appropriate and feasible and acceptable to the community by meeting the applicable procedures. 
8. The establishment of houses of worship in the Temple of Balaji Venkateshwara Wijaya Kusuma Flower No. 25 A Ex. Padang Bulan Medan Selayang II. The presence of residents who objected to the establishment of Balaji Venkateshwara Temple at Bunga Wijaya Kusuma road No. 25 A Ex. Padang Bulan Medan Selayang II. This problem has been resolved by FKUB Medan.

9. Potential conflicts are quite vulnerable is supporting the incident made Tapanuli Province (SOP) in 2009 at the Parliament Building which resulted in the death of northern Sumatra North Sumatra DPRD chairman. Board FKUB North Sumatra with alacrity and soon it was time to gather and dialogue with the leaders of religious assemblies to express attitudes and collective agreements that the event is not a problem interfaith, but a criminal act.

10. Renovation Church in Hamlet III HKBP Voluntary Road East Village District of Percut Dendang Sea Sei Tuan Deli Serdang. The objections of citizens over renovation HKBP Voluntary Hamlet III Road East Village District of Percut Sei Tuan Laudendang Deli Serdang. This problem has not been completed by the Deli Serdang FKUB.

11. Development Amithaba statue at the Vihara Tri Ratna in Tanjung Balai. Society demands that placement moved, the original Buddha Guidance Director General has agreed with the letter Number: DJ.VI/3/BA.02/604/2010, then the letter is withdrawn under letter No. DJ.VI/3/BA.02/680 / 2010 dated June 23, 2010, the Regional Office of the Ministry of policies beyond handing North Sumatra and Tanjung Balai town government.

12. Lord Ganesh and Krishna in Sandal circulating in Medan, protests from the Hindu community and PHDI. Until now there is no solution.

13. Throwing mosque which resulted in the burning kiosk concurrently motorcycle shop owned by the named Parlindungan Nababan in Bandarpulau shavings. Has been completed by the local government with FKUB but players still throwing in the affairs authorities.

14. Ambush was carried about 300 people against Muslims in the village of Kampung Melayu Selambo Sandpaper District of Percut Sei Tuan Deli 
Serdang and Masjid al-Barokah stoned, and burned 7 houses and damaged five other units, and damage to plant communities, on the 30th October 2010.

15. Burning mosque in Toba Samosir Lumbanlobu. Experiments have repeatedly firing, last firing on July 27, 2010, FKUB North Sumatra and Toba Samosir FKUB mediation so that the public has not moved, but so far police have not detained offender's combustion.

16. Use of shop and plaza as a place of worship that are unlicensed, many occur in cities that ignore the PBM No. 9 and 8 of 2006.

17. Spread 17th book nuanced harassment and defamation of a religion in Medan and Labuhan district. One among the perpetrators have been arrested.

18. Burning of two mosques in the village of Aek Loba District of Aek Kuasan Asahan, on 30 March 2011 in North Sumatra and FKUB FKUB Asahan District, along with local government and the local police chief consulted, and agreed to be submitted to the authorities. Conflict and the matter are finished.

19. Backlash against construction of a mosque of al-Munawarah Sarulla Pahae Jae District of North Tapanuli since 2010 until now could not be established. Settlement efforts have been taken through the applicable rules and procedures, as well as the deliberation initiated by the government and FKUB, but the mosque building permits are not issued, to this day has not been completed.

Most have done well and some are still in the process of completion that must be addressed. Among the issues that arise in the above is the danger of disintegration. Symptoms that indicate the threat comes in many forms such as horizontal conflicts in some places, which is linked to economic factors, political and cultural. In addition, perhaps due to ignorance and religious disobedience against PBM No. 9 and 8 years 2006 is the massive conflict when religious sentiment and the influence of various events. Infighting between groups in society, in turn, can be a threat to the integrity of the Unitary Republic of Indonesia.

Surely that is more important is how the implementation of the Joint Ministerial Regulation (PBM) No. 9 and 8 years 2006 on guidelines for the implementation of the tasks of regional head / deputy regional head in the 
maintenance of religious harmony and the establishment of the synagogue. Because, until now, still not optimal. This effort, indeed, not as a job flipping hand side. Moreover, if seen from the readiness budget for FKUB in various regions. Thus, safety, comfort and harmony into something expensive. Has made various efforts to establish dialogue among others, the college president interfaith, interfaith women, youth inter-religious, inter-religious hawkers, fishermen interfaith dialogue about the relationship of religion, by nationality understanding, prayer held each faiths together in the field in North Sumatra event Prayer, interfaith dialogue with leaders in the areas in almost all districts / cities as North Sumatera. Aside from that, realize also that a variety of potential triggers of conflict in this area is not solely stem from religious differences but also of social problems collectively perceived by adherents of the religion. For those reasons, the dialogues between religious leaders and leaders of local government is not done. The meeting was intended to discuss in detail and in-depth development issues that are and will be faced by the people such as gambling, prostitution, drugs, land, corruption, poverty and so on.

Resolution religious harmony majority and minority faiths of Islam and Christianity in North Sumatra is not just desired to maintain and preserve a situation there is no conflict and tension. Harmonious situation must be viewed from the context of the development of the community who are working to build, and who face a variety of challenges. It means harmony in embodied interaction is a dynamic state that is part of the growth and development of communities in North Sumatra. To promote harmony in the interaction between religious life, then every religious believer that the majority and minorities, both Muslims and Christians need a mutual tolerance, mutual tolerance and gracefully, even if it seems so hard, but need to be developed and preserved in between.

In an attempt to create religious harmony in North Sumatra role of religion and the role of religious institutions is very urgent, because the role of religion and religious institutions in social change or social transformation embodied in the form of civil societyare not walking alone. This requires a perpetrator to the media or make changes. One of the agents of the change was quite strategic, and dependable are the institutions that are in the middle of a plural society itself.

In the context of inter-religious harmony idealization in Indonesia, Sjadzali $(1991,18)$ suggested that in dealing with national issues should all people of different 
religions can think and act as a unified whole with a single goal, namely the development success. The issue is not whether religion is dividing uniting factor or factors alone, because now it should be more advanced, the need to secure the country and the development and solver factors, including a split in the religious teachings (Sjadzali 1991, 18).

Sjadzali $(1991,18)$ also said that the difference between the top layer (the Government), and the bottom layer (the people) are reflected in the policies and renewal process in Indonesia, directly or indirectly cause problems also in the level of inter-religious harmony. At the very least, conflict-religious conflicts (Sjadzali 1991, 18). Then to realize and live in harmony and peace unite coveted Indonesian children in this nation ultimately requires serious efforts to involve the role of religion itself, the role of religious leaders, intellectuals, civil society and the role played by various institutions in the name of religion.

Chronologically, the main issues underlying the conflict between religious communities in Indonesia, particularly in North Sumatra is religious broadcasting and the establishment of houses of worship, including any prejudice either against a particular group, the existence of discrimination, economic gaps, and the differences in ideology (Fathurrahman, 1986: 238). Those factors that lead to inter-religious conflict in North Sumatra, but then the people in the conflict between the different religious communities, has its own strategy or resolution to establish an atmosphere of peace and harmony, among the strategies that built it is to use the approach cultural, structural, dialogue, inter-religious discussion, both Muslims and Christians.

However, it should be understood that the above strategy and the resolution which has been initiated by the government and religious leaders to upholding aspects of life of the nation by developing the concept of harmony and religious tolerance in Indonesia needs to be reviewed, because the strategy undertaken by the government appears not maximized, by because it needs to be followed up seriously and sincerely. For though the various formulations of the dialogue which was built by the government and religious institutions such as; Indonesian Ulema Council (MUI), Indonesian Communion of Churches (PGI), Parisadha Hindu Dharma Indonesia (PHDI), Representative of the Indonesian Buddhist (WALUBI) and Forum Kerukunan Umat Beragama (FKUB) in Indonesia has not been able to 
deliver the resolution and organizing social conflicts religious well, because the spirit of cohesion has been seen as a public duty.

Therefore, it is necessary or proper resolution strategy to build inter-religious harmony in North Sumatra should still refer to the Pancasila and the 1945 Constitution as the basis for the State and for the final ideologies among religious communities in Indonesia, including Unity in Diversity, State Unitary Republic of Indonesia (Homeland), because the survival of the nation, and religion in North Sumatra are very dependent on four things above as a unifier between religious communities as described in the state motto "unity in Diversity" which unified despite each difference in variance. Chronologically there are several strategies adopted as a resolution to the impact of majority and minority religions of Islam and Christianity in North Sumatra.

\section{Using cultural approach}

Cultural approach is one of the strategies in managing the majority and minority of Moslems and Christians in North Sumatra, because with this approach can bring the tradition of a pluralistic society in the form of local wisdom actualization. Local Wisdom is indeed universal values of religion and culture that is manifested in the local tradition. So, by using inter-religious cultural approach can be reconciled, and each religion has become entrenched or grounded in the midst of people of different religions, so that they can make peace between religious communities, and work in harmony.

\section{Using the structural approach}

Structural Approach one of the strategies to build and maintain the majority and minority groups in North Sumatra. This approach is meant is the harmony institutions, both of which were taken by non-governmental organizations engaged in the community and the idea of harmony and new institutions introduced by the government. Through this structural approach also adherents among people of Bergama can met by Believers in the form of harmony through various religious institutions in Indonesia. One example is FKUB can establish partnerships with various programs harmony of the Research Institute for Religious Harmony (LPKUB).

Similarly, the role of the Indonesian Ulema Council (MUI) of North Sumatra province in the early detection of phenomena which brought disruption of religious 
harmony, as well as reviewing every social and religious conflicts are very relevant to the task of PGI about harmony. According to them the true and genuine harmony is someone not relativize the difference and not too dissolve it in ordinary things may be connected, dialogue and collaboration (Soetapa, 1987: 7). Similarly, with other religious institutions can find a strategy to build peace between the majority and minority faiths of Islam and Christianity in North Sumatra.

\section{By using dialog approach}

One way in between the majority and minority of Moslems and Christians in North Sumatra have mutual openness, while affirming it is to intensify the dialogue, because the dialogue approach is also an appropriate resolution in building peace between faiths, because according to Said Agil Husin Al-Munawar that religious harmony in Indonesia is one of the results of the dialogue. In harmony with Bassam Tibi said that dialogue is the best way to make sense in order to establish peace in the world. But the discourse of what should be used in this kind of dialogue? then there must be a common consensus about the forms of discourse that will be agreed upon by all parties (Madjid et al. 1996, xxii), both of the adherents of the majority religion and the minorities.

With this approach also dialogue between the majority and the minority Muslims and Christians in North Sumatra can be brought together in creating peace. With this dialog all religious and social issues can be resolved and agreed upon between the respective religions. This dialogue discourse is an appropriate resolution, and continue to be extracted and cultivated at this time, both the doctrines of religions, as well as on cooperation and other social relationships. In addition to the above approach, there are also four other strategies that have been implemented as a resolution to the impact of majority and minority in North Sumatra, namely Pancasila, the Constitution of 1945, Unity in Diversity, and the Republic of Indonesia (Homeland), because the survival of the nation Indonesia will depend on four things mentioned above.

Religious diversity in the community at the same time often is ethnic diversity, is one of the cultural treasures as well as potential conflicts found in the lives of the people of North Sumatra. Therefore, in the daily life of the people in North Sumatra found a harmony on one hand, but on the other hand there is also a conflict or disagreement. However, so far North Sumatra and surrounding 
communities have mechanisms to reduce conflict. One of the mechanisms in question is the concept Dalihan Natolu (three furnaces). Likewise, the kinship system in the form of clan society has become adhesive. Some of these mechanisms has become a meeting point for the people of North Sumatra to keep a harmonious relationship despite their different religions. Another factor that can reconcile interreligious, inter alia besides aegis of government, leadership is also quite religious institutions also influence.

Besides various conflict resolution mentioned above, the resolution of which has been done to prevent conflicts among others; into the teaching of religion as a unifying factor (integrative) in public life. Implement the religious understanding that is moderate, without sacrificing the basic teachings of religion. This kind of understanding will result in religious teachings that promote compassion (rahmah), peace (Salam), tolerance (tasamuh) in inter-human relations. In line with that which is not less important is the strengthening socialize morality (ethical-moral) and the character of the nation. Therefore, strengthening of character and this character becomes a necessity, both within the family, school, community and work / profession, through "strengthening movement morals and character of the nation", by way of intensifying dialogue and enhanced cooperation among religious believers, both in the economic and social.

\section{Conclusion}

Pluralistic societies tend to encourage the development of North Sumatra understanding of ethnic prejudice and ethnocentrism ethnic stereotypes. The potential is initially in the form of conflicts between individuals and then widens into a social conflict involving the mass of a particular ethnic power. It is clear that the individual has the potential to develop into a conflict social conflict involving ethnic, social and interfaith groups. Of all the roots of the conflict is about identity issues, life safety, and economic resources of the people. Therefore, the dominant conflict occurs in this area stems from conflict resources in natural resource tenure conflicts and economic resources, not because of religious teachings. While conflicts related to religious and cultural identity is relatively small and low.

While the potential for conflict; First, the issue of Christianization and Islamization phenomenal. Second, the difference in ideology and practice of religious 
teachings are not in line with the mainstream understanding of the religion. Third, less healthy political competition that carries religious symbols. Fourth, the difficulty of finding someone who is seen representative, authoritative acceptable among a wider variety. Fifth, the process of weakening religion and local wisdom due to global culture. Sixth, Development and use of places of worship are not in accordance with the PBM 2006 Seventh, the narrowness of religious insight someone to another religion.

If the mapping potential of realizing harmony and the potential for conflict in general it can be concluded that the factors supporting the preservation of harmony is; First, the commitment and political support of the religious leaders and local government. Second, economic life and improved social inequalities. Third, messages and values and religious teachings which enabled local indigenous of harmony. Fourth, the double role of religious leaders in various social units, and willingness understand other religions. Fifth, multicultural dialogue across religious, ethnic, cultural actually grew from the needs of the religious community itself. In turn provide opportunities for mutual open, honest and willing to understand and appreciate people from other religions. It is this attitude which has been developed by religious leaders in North Sumatra, so this area remains to be excellent and a barometer of national harmony.

\section{References}

Ackermann, R. J. (1997). Agama sebagai Kritik: Analisis Eksistensi Agama-agama Besar [Religion as Critique: Analysis Existence of the Great Religions]. 2nd ed. Jakarta: BPK Gunung Mulia.

Agustono, B. et al. (2013). The Governor of North Sumatra, Study of History, Social, and Cultural Rights. Medan: USU Press.

Al Faruqi, I. R., ed. (1995). Trialogue of the Abrahamic Faiths. Beltsville: Amana Publications.

Ali, A. Y. (1992). The Meaning of The Holy Qur'an. New York: Amana Corporation.

Anderson, B. R. O'G. (1961). Same Aspects of Indonesian Politics Under the Japanese Occupation: 1944-1945. Ithaca: Cornell University.

Ardon, P. (1997). Conflict in Central America. New York: Oxfam Internal Document. 
As Sirjani, R. (2015). The Harmony of Humanity. 1st ed. Translated and Edited by Fuad Syaifudin Nur, Masturi Irham, M. Abidun Zuhri, and Ferdian Hasmand. Jakarta: Pustaka Al-Kautsar.

Atho, M. (2004). "The Challenge of Religious Contributions in Multiculturalism Achieve." Journal of Harmony 11 (3): 11.

Azra, A. (2002). Konflik Baru Antar Peradaban: Globalisasi, Radikalisme \& Pluralitas [New Conflicts Between Civilization: Globalization, Radicalizm \& Plurality]. 1st ed. Jakarta: RajaGrafindo Perkasa.

Bellah, R. N. (1969). Beyond Belief: Essays on Religion in a Post Traditional World. New York: Evanston and London.

Budiman, A., ed. (1991). State and Civil Society in Indonesia. Clayton: Center of South East Asia Studies Monash University.

Chandoke, N. (1995). State and Society: Exploration in Political Theory. New Delhi: Sage Publications Indonesia.

Dictionary Drafting Team Development and Language Development Centre in (IMEC) Indonesian Ministry of Education and Culture. (1989). Big Indonesian Dictionary. 2nd ed. Jakarta: Balai Pustaka.

Dirks, J. F. (2006). The Abrahamic Faiths: Judaism, Christianity, and Islam Similarities and Contrast. 1st ed. Translated and Edited by Santi Indra Astuti and Helmi Mustofa. Jakarta: PT. Serambi Ilmu Semesta.

Drajat, Z. et al. (1996). Perbandingan Agama [Comparative Religion]. Jakarta: Ministry of Religious Affairs of Indonesia.

Echols, J. M. (2000). An English-Indonesian Dictionary. Translated by Shadily Hasan. Ithaca and London: Cornell University Press.

Fathurrahman, A. (1986). "Social Conflict and Conflict-Community Integration." Basic Social Sciences, edited by Darmansyah et al. Surabaya: Usaha Nasional.

FKUB Sumatra. (2008). Harmony Media FKUB Sumatra. 4th ed. Medan: FKUB Sumatra Press.

Guillaume, A. (1970). The Life of Mubammad: A Translation of Ibnu Ishaq's Sirat Rasul Allah. Karachi: Oxford University Press.

Hart, M. H. (1990). The Hundred Most Influential People in History. Translated by M. Djunaedi. Jakarta: Pustaka Jaya.

Hidayat, K. and Gaus A. F., eds. (1998). Passing Over: Melintasi Batas Agama [Passing Over Crossing Borders of Religion]. Jakarta: PT. Gramedia Pustaka Utama.

Huntington, S. P. (1993). "The Clash Between Civilizations, The Future of World Politics?" Ulumul Qur'an 5 (4): 12. 
Lund, M. S. (1996). Preventing Violent Conflict: A Strategy for Preventive Diplomacy. Washington: United States Institute of Peace.

Madjid, N. (1992). Islam: Doktrin dan Peradaban: Sebuab Telaah Kritis tentang Masalab Keimanan, Kemanusiaan, dan Kemodernan [Islam: Doctrine and Civilization: A Critical Review on Issues of Faith, Humanity, and Modernity]. Jakarta: Paramadina Endowment Foundation.

Madjid, N. et al. (1996). Religious and Inter-Civilization Dialogue. Jakarta: Paramadina.

Mitchell, C. (1981). The Structure of International Conflict. London: Macmillan.

Pelly, U. and Asih Menanti. (1994). Teori-teori Sosial Budaya [Social Theories of Culture]. Jakarta: Directorate General of Higher Education.

Pringle, R. (2018). Islam di Tengah Kebhinnekaan: Memahami Islam dan Politik di Indonesia [Islam in the Midst of Diversity: Understanding Islam and Politics in Indonesia]. 1st ed. Translated by Tri Wibowo BS. Jakarta: Prenada Media Group.

Ricoeur, P. (1986). Lectures on Ideology and Utopia. New York: Columbia University Press.

Ross, M. H. (1993). The Culture of Conflict. London: Yale University Press.

Shihab, A. (1999). Islamic Inclusive: Attitudes Towards Open in Religion. London: Mizan.

Sjadzali, M. (1991). Religion and Pluralism Indonesian Society. Jakarta: P3M.

Soetapa, D. (1987). Dialog Kristen-Islam: Suatu Uraian Theologis [Christian-Islam Dialogue: A Theological Description]. Yogyakarta: Centre for Research and Education in Ambassador Discourse.

Soroush, A. K. (2002). Sue Authority and Tradition Religions. London: Mizan.

Taha, A. A. (1996). Political Islam and the State in New Order. Jakarta: Gema Insani Press.

Tamara, N. and M. E. P. Taher, eds. (1996). Religious and Inter-Civilization Dialogue. Jakarta: The Paramadina Foundation.

Widodo et al. (2002). Popular Dictionary of Scientific Terms Comes EYD and Formation. 2nd ed. New York: Absolut.

Yewangoe, A. A. (2002). Religion and Harmony. Jakarta: BPK Gunung Mulia, 2nd Printing. 